\title{
Production of Clay Containers for Curbing Plantain Post-Harvest Losses in Ghana
}

\author{
Kofi Asante-Kyei, Alexander Addae, Mercy Abaka-Attah \\ Takoradi Technical University, Takoradi, Ghana \\ Email: kofi.asante-kyei@ttu.edu.gh, alexander.addae@ttu.edu.gh, mercy.abaka-attah@ttu.edu.gh
}

How to cite this paper: Asante-Kyei, K., Addae, A. and Abaka-Attah, M. (2019) Production of Clay Containers for Curbing Plantain Post-Harvest Losses in Ghana. New Journal of Glass and Ceramics, 9, 50-65. https://doi.org/10.4236/njgc.2019.93005

Received: June 12, 2019

Accepted: July 23, 2019

Published: July 26, 2019

Copyright () 2019 by author(s) and Scientific Research Publishing Inc. This work is licensed under the Creative Commons Attribution International License (CC BY 4.0).

http://creativecommons.org/licenses/by/4.0/

\section{(c) () Open Access}

\begin{abstract}
In Ghana, most farmers are peasants and at times foodstuffs produced get rotten either through transportation or market places. This normally affects the meager income that farmers earn through hard work. Available statistics indicate that each year, food crops worth several hundreds of dollars go waste in the country due to poor harvest losses and it represents $70 \%$ of total food production in Ghana. Again, in the country, there is abundant of clay as a natural resource. Geological study has revealed that it is found in almost every part of the country. As a means of finding solution to the rate at which local foodstuffs especially plantain rot, the study sought to design and compose clay container purposefully for storing plantain to prolong its lifespan. The study focused on 5 clay body compositions $\left(C_{1}\right.$ to $\left.C_{5}\right)$ and fired at $950^{\circ} \mathrm{C}$. Composition $\mathrm{C}_{1}$ consisted of $50 \%$ of Abonko clay and $50 \%$ of Daboase clay. Composition $\mathrm{C}_{2}$ was made up of $40 \%$ Abonko clay, $50 \%$ Daboase clay and $10 \%$ of smooth sawdust. Composition $\mathrm{C}_{3}$ composed of $45 \%$ of Abonko clay, $45 \%$ of Daboase clay and $10 \%$ of smooth sawdust. Composition $\mathrm{C}_{4}$ was made up of $90 \%$ Daboase clay and $10 \%$ rough sawdust. The last composition $\mathrm{C}_{5}$ comprised mainly 100\% Abonko clay. Fresh plantains obtained from Takoradi market circle were stored in the containers and weekly recordings of states of plantain for five consecutive weeks were carried out. It was revealed that $\mathrm{C}_{4}$ was successful in storing fresh plantains to ripe stage after the five weeks. It is recommended among others that, the technique should be made available to stakeholders such as Ministry of Food and Agriculture (MOFA), plantain farmers and market plantain sellers through seminars, public education and symposia in order to minimize post-harvest losses.
\end{abstract}

\section{Keywords}

Clay, Containers, Plantain, Storage 


\section{Introduction}

In Ghana, the loss of foods in the post-harvest system has been a problem, and there is the exigency to do a better job of conserving or expanding the shelf-life of food supply in order to ease hunger and undernourishment. The agricultural sector responsible for food production supplies the majority of crops including fruits and vegetables that are seasonal crops and perishable in nature. Available statistics indicate that each year, food crops worth Seven Hundred Thousand Dollars $(\$ 700,000.00)$ go waste in the country due to poor harvest losses and it represents $70 \%$ of total food production in Ghana [1]. A good number of studies on post-harvest technology have been undertaken and concentrated on grains and other durable products, which are generally stored dry, and a considerable technology has been developed to deal with these problems. On the other hand, little work has been conducted on the perishable food crops, yet they are of great importance and contribute portions of the diets in developing countries such as Ghana. According to a Food and Agriculture Organization (FAO) survey in 2006 , plantain contributed about $13.1 \%$ of the agricultural gross domestic product (AGDP) and per capita annual consumption of $101.8 \mathrm{~kg}$ per head in Ghana [2]. There are crops of great economic value with a hope of local consumption, export market, and play a big role in food security and poverty reduction. They are also essential sources of nutrients, minerals, and vitamins for human health and wellbeing [3]. During good seasons, there may be pumper harvest, especially plantain, but due to lack of good roads, inadequate transport facilities and poor availability of packing materials, the surplus cannot be conveyed quickly to the markets in urban centres. In addition, the surplus production often cannot be stored for sale during off-seasons because of insufficient local storage facilities [4]. In other words, the farmers and foodstuff sellers do not achieve good prices for their produce because of the pumper harvest and most of the crops get spoilt resulting in complete loss of income. According to Asarewaa [5], fresh plantains take less than two weeks to get rotten at the Ghanaian market centres and it is a big challenge for plantain sellers. In effect, the ultimate aim of preserving food is to reduce the growth of microorganisms during the storage stage, thus facilitating longer shelf life and minimizing hazard from eating the food [6]. According to Hagan [6], some modern preservation methods of food include: 1) canning-process of preserving food by heating and sealing it in containers for storage; 2) dehydration-longer storage through sundry, room dry and dehydrators; 3) freezing and freeze-drying-creating environment where bacteria cannot grow. Freeze-dried foods lust months to years. For example, sea food and fruit juice; and 4) irradiation-food is exposed to a controlled amount of radiation to destroy organisms responsible for spoilage.

\subsection{Objectives of the Study}

1) To investigate possibilities of composing clay bodies to manufacture clay containers for storing plantain.

2) To determine whether the manufactured clay containers can increase the 
life-span of plantain.

3) To provide local plantain farmers and sellers alternative means of storing plantain.

\subsection{Importance of the Study}

The study will be useful to peasant farmers and market dealers especially plantain sellers, in order to maximize profit or income.

\subsection{Research Question}

To what extent can composed clay containers store and prolong shelf-life of plantains as foodstuff?

\subsection{Delimitation (Scope)}

The study is limited to the use of composed clay bodies to manufacture clay containers that will be used to store plantain.

\subsection{Brief Overview of Food Storage}

Foods are materials, raw, processed, or formulated, that are consumed orally by humans or animals for growth, health, pleasure, satisfaction, and satisfying social needs [7]. Food by its nature starts to deteriorate the moment it is harvested. Physical, chemical, mechanical, and microbial effects are the leading causes of food deterioration and spoilage. Rahman [7] argues that damage can start at the initial point by mishandling of foods during harvesting, processing and distribution; and may lead to ultimate reduction of shelf life. Rahman [7] outlines other instances of deterioration as follows: 1) bruising of fruits and vegetables during harvesting and postharvest handling, leading to the development of rot, 2) tuberous and leafy vegetables lose water when kept in atmospheres with low humidity and, subsequently, wilt, and 3) dried foods kept in high humidity may pick up moisture and become soggy. Food storage involves the action taken to maintain foods with the desired properties or nature for as long as possible [7]. In Ghana, it is a common practice to see different containers such as wood box, plastic materials, baskets, and sacks used in collecting various farm produce during harvesting with inadequate handling that enhances level of produce damage. Food scientists have described that absence of farm storage facility and proper packing systems results in perishable produce being marketed immediately after harvesting without primary processing and adequate packaging [8]. According to Brummell [9], the main reasons for storing food are to overcome inappropriate planning in agriculture, produce value-added products, and provide variation in diet. In ancient times, farmers used the sun and wind to naturally dry food. Evidence proved that Middle East and oriental cultures actively dried foods in hot suns as early as 12,000 B.C. [10]. Freezing was also an obvious preservation method to the appropriate climates. People who lived in geographic areas that had freezing temperatures for some part of a year made use of the 
temperature to store foods [11]. Another method termed fermentation was also used in some parts of the world. It was not invented but rather discovered when first beer was outlined as a result of few grains of barely were left in the rain and microorganisms fermented the starch-derived sugars into alcohols [10]. In another development, majority of studies have shown that the most common causes of post-harvest losses include lack of sorting to eliminate defects before storage and the use of inadequate packaging materials, rough handling and inadequate cooling and temperature maintenance [12].

\section{Local Storage of Plantain}

In Ghana, the bumper harvest of plantain in the food growing areas such as Agogo, Maame Krobo in the Afram Plains, Hwediem and Gaoso as well as several plantain growing areas make it difficult for farmers to store plantain before transporting them to market. Post-harvest loss assessment of plantains were carried out in Market Circle, Takoradi and the result revealed that there were greater post-harvest losses of $53.3 \%$ due to poor handling during transportation and the use of poor marketing structures to sell their plantains [13]. Some sellers adopted crude methods by covering their foodstuffs with fabric and also sold in the open space being exposed to direct sunlight; leaving them at the mercy of the weather as demonstrated in Figure 1. These outmoded methods of trying to store plantains rather worsen the situation thereby making the plantain foodstuffs ripe or get rotten in no time. This situation becomes serious for plantain farming, especially during bumper harvest and requires urgent attention. The short shelf-life of plantain makes it difficult to manage easily post-harvest period unlike that of dry grains [14]. Hence, the attempt by the researchers to experiment and find if possible, an enduring solution to plantain getting rotten by adopting the use of clay containers as a method of storing fresh plantain to expand its shelf-life.

\subsection{Clay Deposits in Ghana}

Clay deposits are located in all regions of Ghana. According to Kesse [15], work has been done on the occurrence of clay deposits in Ghana, including the location, reserves in metric tonnes, approximate expected life span of the clay deposit in years and the possible usage of the deposits. Table 1 and Table 2 represent the location, area and reserve of the clay deposits in Ghana.
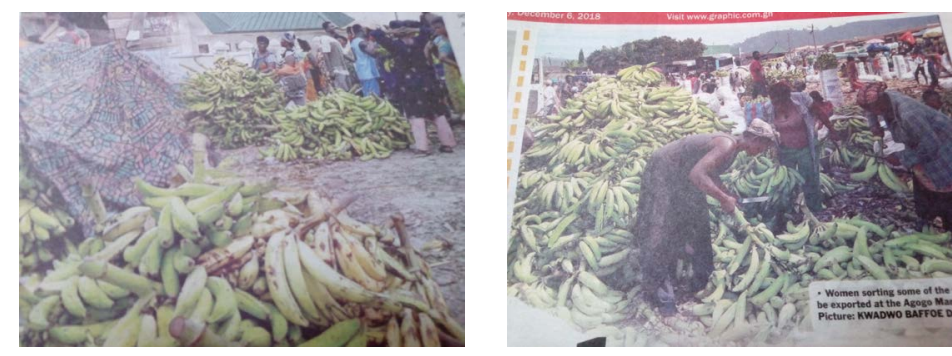

Figure 1. Methods of storing plantain at the mercy of the weather in Market Circle, Takoradi. 
Table 1. Clay deposits in the greater Accra, Brong Ahafo, Upper, Central regions of Ghana (Kesse, 1985).

\begin{tabular}{|c|c|c|c|c|c|}
\hline \multicolumn{6}{|c|}{ Greater Accra Region } \\
\hline Area & Location & Reserve (tonnes) & Area & Location & Reserve (tonnes) \\
\hline \multirow{7}{*}{ Accra } & Alajo & 48,600 & \multirow{4}{*}{ Tema } & & \\
\hline & Ashiaman & $18,677,165$ & & Afienya East & $24,194,681$ \\
\hline & Prampram A & $21,779,929$ & & Afienya West & $5,514,894$ \\
\hline & Prampram B & 74,350 & & Mobole & $15,000,000$ \\
\hline & Prampram C & 43,771 & \multirow[t]{3}{*}{ Ada } & Kasseh/Bedaku & $42,661,830$ \\
\hline & Kpone & $\begin{array}{c}10,960,115 \\
6735\end{array}$ & & Big Ada & $51,242,553$ \\
\hline & $\begin{array}{l}\text { Oyibi } \\
\text { Kabenva }\end{array}$ & $\begin{array}{c}6735 \\
2,326,596\end{array}$ & & & \\
\hline \multicolumn{3}{|c|}{ Brong Ahafo Region } & \multicolumn{3}{|c|}{ Upper Region } \\
\hline Area & Location & Reserve (tonnes) & Area & Location & Reserve (tonnes) \\
\hline \multirow{4}{*}{ Sunyani } & & & \multirow{4}{*}{$\begin{array}{l}\text { Bolgatanga/ } \\
\text { Navrongo }\end{array}$} & Gambibigo & $12,419,998$ \\
\hline & Susan Valley & $\begin{array}{l}661,188 \\
16200200\end{array}$ & & Sumbrungu & 4020 \\
\hline & Tanoso & $16,200,200$ & & Tono & $8,477,333$ \\
\hline & & & & Sobolo & 649,997 \\
\hline \multicolumn{6}{|c|}{ Eastern Region } \\
\hline Area & Location & Reserve (tonnes) & Area & Location & Reserve (tonnes) \\
\hline \multirow[t]{3}{*}{ Nkawkaw } & Adihima/Asuogya & $2,240,099$ & Asamankese & Asamankese & 840.000 \\
\hline & Abepotia & $7,614,793$ & \multirow{2}{*}{ Akim Oda } & Apinmang & $2,801,250$ \\
\hline & Framase & 41,687 & & Akim Swedru & $33,173,335$ \\
\hline \multirow[t]{2}{*}{ Kibi } & Tamfoi & $1,285,084$ & \multirow{4}{*}{$\begin{array}{l}\text { Akwapim } \\
\text { Somanya }\end{array}$} & Akim Awisa & $1,285,553$ \\
\hline & Moseaso & 444,000 & & Akim Abonase & $4,561,000$ \\
\hline \multirow{2}{*}{ Anyinam } & Abomosu & $\begin{array}{c}444,000 \\
4.081,434\end{array}$ & & Adawso & $1,027,000$ \\
\hline & & & & Okwenya & $34,862,223$ \\
\hline \multicolumn{6}{|c|}{ Central Region } \\
\hline Area & Location & Reserve (tonnes) & Area & Location & Reserve (tonnes) \\
\hline \multirow[t]{5}{*}{ Cape Coast } & Nkuntraw & $7,527,168$ & Winneba & Esuakyir No 2 & $1,800,000$ \\
\hline & Kakum Valley & 42,800 & & Simbrofo & $3,100,000$ \\
\hline & Atrankwa & $12,000,000$ & & Mprumen & 35,877 \\
\hline & Ochiso & $15,441,702$ & & Kasua/Oduponkpehe & $51,702,127$ \\
\hline & Ampia Ajumaku & 195,000 & & Nyanyanu & $1,107,191$ \\
\hline Ajumaku & Esuakyir No 1 & $6,800,000$ & Gomoa & Gomoa Brofo & 268,968 \\
\hline Dunkwa & Subin Valley & 162,000 & Komenda & Domenase & $3,952,551$ \\
\hline
\end{tabular}

Table 2. Clay deposits in the Northern, Western, Ashanti and Volta regions of Ghana (Kesse, 1985).

\begin{tabular}{|c|c|c|c|c|c|}
\hline \multicolumn{6}{|c|}{ Northern Region } \\
\hline Area & Location & Reserve (tonnes) & Area & Location & Reserve (tonnes) \\
\hline Tamale & $\begin{array}{c}\text { Koblimahago } \\
\text { Kpaliga } \\
\text { Nyankpala }\end{array}$ & $\begin{array}{c}9,455,892 \\
259,200 \\
48,600\end{array}$ & Tamale & $\begin{array}{c}\text { Kunkuo } \\
\text { Yapei }\end{array}$ & $\begin{array}{c}234,502 \\
38,694\end{array}$ \\
\hline \multicolumn{6}{|c|}{ Western Region } \\
\hline Area & Location & Reserve (tonnes) & Area & Location & Reserve (tonnes) \\
\hline
\end{tabular}




\begin{tabular}{|c|c|c|c|c|c|}
\hline \multicolumn{6}{|l|}{ Continued } \\
\hline \multirow{8}{*}{ Nzima } & AlendaWharf & $2,956,522$ & \multirow{3}{*}{$\begin{array}{l}\text { Sekondi } \\
\text { Takoradi }\end{array}$} & Inchanban & \multirow{3}{*}{$\begin{array}{l}2,668,600 \\
7,163,082 \\
9,469,979\end{array}$} \\
\hline & Aluku & $17,860,944$ & & Shama & \\
\hline & Esiama-Kakam & $113,550,239$ & & Dixcove (Mfruma) & \\
\hline & Teleku-Bokaso & $74,456,122$ & \multirow{2}{*}{ Wasa } & Wasa-Akropong & 614,249 \\
\hline & Nimzimirim & $9,343,117$ & & Asankragwa & $8,629,200$ \\
\hline & Bao-Bamakpolo & $31,493,879$ & \multirow{3}{*}{ Amanfi } & Enchi & 226,330 \\
\hline & Bokazo & $221,600,000$ & & Manso-Amanfi & 597,780 \\
\hline & Nzima East & $241,190,133$ & & Mranso-Amantil & \\
\hline \multicolumn{6}{|c|}{ Ashanti Region } \\
\hline \multirow[t]{3}{*}{ Area } & Location & Reserve (tonnes) & Area & Location & Reserve (tonnes) \\
\hline & Womasi & 164,570 & & & \\
\hline & Kaasi (Tuantem) & $1,086,993$ & & & \\
\hline \multirow{8}{*}{ Kumasi } & Sisai & 113,400 & & Asokwa & $33,865,955$ \\
\hline & Kokobriko & 21,061 & & Mfensi & 396,548 \\
\hline & Dichemso-Valley & 81,000 & Obuasi & Afari & $2,055,900$ \\
\hline & Aboabo & 162,017 & Nkawie & Jankoba & 139,999 \\
\hline & Dichemso-Aprapong & 162,017 & & Ahatawsu-(Mpasatia) & 100,560 \\
\hline & Satang No 1 & 32,400 & & Awrenfena & 268,801 \\
\hline & Satang No 2 & 162,017 & & & \\
\hline & Subin Valley & 162,900 & & & \\
\hline \multicolumn{6}{|c|}{ Volta Region } \\
\hline \multirow[t]{3}{*}{ Area } & Location & Reserve (tonnes) & Area & Location & Reserve (tonnes) \\
\hline & Adidome Nol & $7,755,319$ & & & \\
\hline & Adidome No2 & 469,800 & Bowiri & Kalapka & 501,440 \\
\hline Ho & Tangidome & 7614 & & Tuwotsive & 1944 \\
\hline \multirow[t]{2}{*}{ Anfoega } & Nuzeme & 10,083 & & Amanfro/Anyinase & $2,000,000$ \\
\hline & Toga & 42,163 & Dayi & Dayi River Basin & 997,900 \\
\hline \multirow[t]{2}{*}{ Gbefi-Hoeme } & Kpetoe & 29,160 & Ketekrachi & Woroto & $7,027,707$ \\
\hline & Aveyiboe & 27,540 & & Adankpe & $2,273,361$ \\
\hline \multirow{4}{*}{ Kudzra } & Valexo & 16,300 & Hohoe & Adutor & $35,854,085$ \\
\hline & Aklamapata & 6318 & & Kpolo & $9,413,582$ \\
\hline & Have & 6430 & Kadjebi & Kadjebi & $97,742,979$ \\
\hline & Agbeditive & 12,961 & & & \\
\hline
\end{tabular}

\section{Materials and Methods}

\subsection{Materials}

Basically, clay was the major material used to manufacture the clay containers. Two types of clay deposits were adopted for the study namely; Abonko clay and Daboase clay as shown in Figure 2 and Figure 3 respectively. Small quantity of smooth and rough sawdust shown in Figure 4(a) and Figure 4(b) was also used in the composition.

\subsection{Methods}

Samples of clay materials were processed into finer particles and aged for two weeks. The purpose of the aging was to enhance the plasticity of the clay as demonstrated in Figure 5. After aging, samples were weighed on a scale to compose clay bodies for the manufacturing of the clay containers as shown in Table 3. 


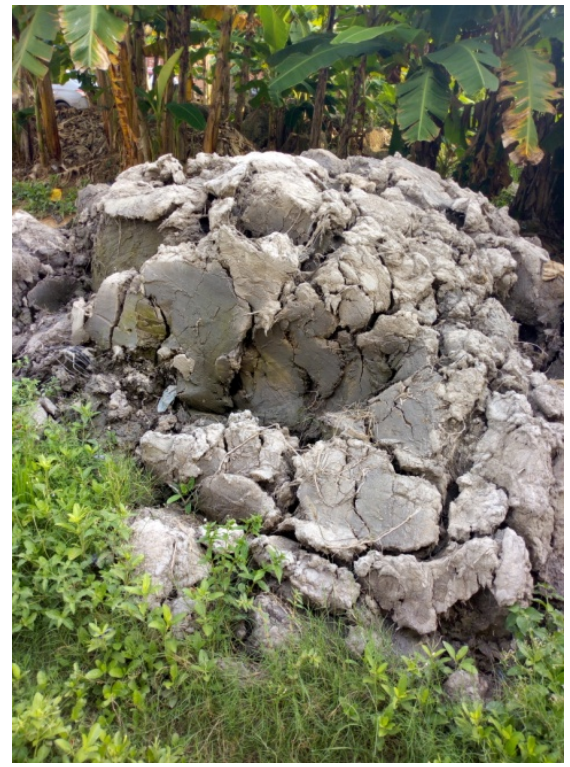

Figure 2. Daboase clay.

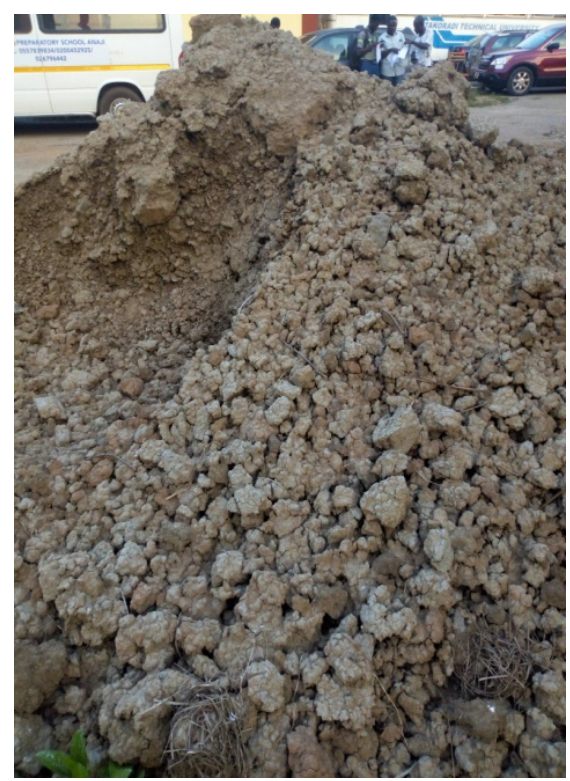

Figure 3. Abonko clay.

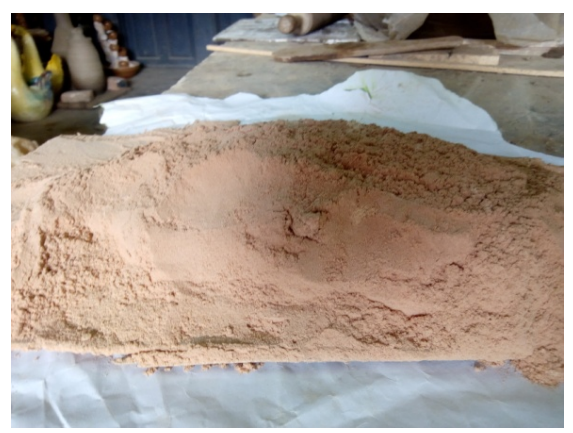

(a)

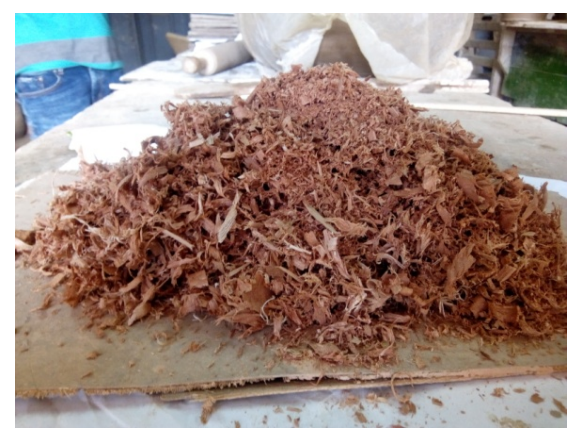

(b)

Figure 4. (a) Smooth sawdust; (b) Rough sawdust. 


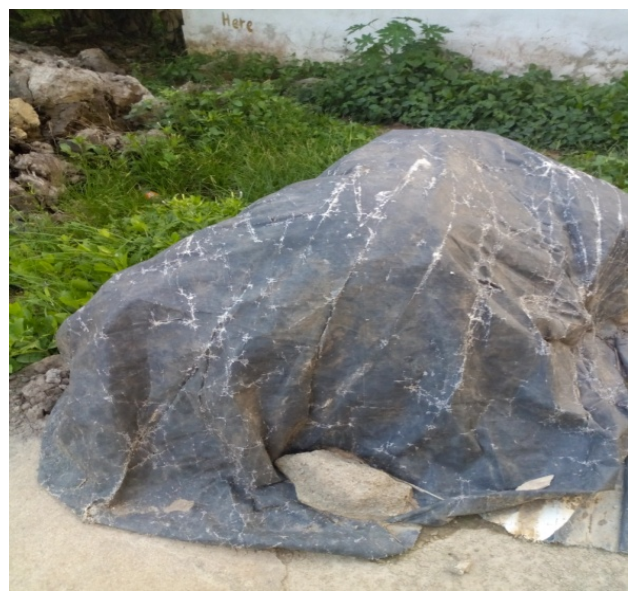

Figure 5. Aging of clay.

Table 3. Composition of Abonko clay, Daboase clay, and sawdust.

\begin{tabular}{ccccc}
\hline $\begin{array}{c}\text { Composition } \\
\text { number }\end{array}$ & $\begin{array}{c}\text { Abonko Clay } \\
\text { weight } \%\end{array}$ & $\begin{array}{c}\text { Daboase clay } \\
\text { weight } \%\end{array}$ & $\begin{array}{c}\text { Sawdust } \\
\text { weight } \%\end{array}$ & Total \% \\
\hline $\mathrm{C}_{1}$ & 50 & 50 & - & 100 \\
$\mathrm{C}_{2}$ & 40 & 50 & 10 (smooth) & 100 \\
$\mathrm{C}_{3}$ & 45 & 45 & 10 (smooth) & 100 \\
$\mathrm{C}_{4}$ & - & 90 & 10 (rough) & 100 \\
$\mathrm{C}_{5}$ & 100 & - & - & 100 \\
\hline
\end{tabular}

From Table 3, five (5) clay bodies were composed as means of experimentation to ascertain which composition would be suitable for the clay container. Composition $\mathrm{C}_{1}$ consisted of $50 \%$ of Abonko clay and $50 \%$ of Daboase clay. Composition $\mathrm{C}_{2}$ was made up of $40 \%$ Abonko clay, $50 \%$ Daboase clay and $10 \%$ of smooth sawdust summing up to $100 \%$. Composition $\mathrm{C}_{3}$ composed of $45 \%$ of Abonko clay, $45 \%$ of Daboase clay and $10 \%$ of smooth sawdust giving a total of $100 \%$. Composition $\mathrm{C}_{4}$ was made up of $90 \%$ Daboase clay and $10 \%$ rough sawdust adding up to $100 \%$. The choice of the rough sawdust became necessary because Daboase clay appeared to be too plastic, hence the need to use rough sawdust in order to miminise, shrinkage and increase the porosity of the container. The last composition $\mathrm{C}_{5}$ comprised mainly $100 \%$ Abonko clay.

\subsubsection{Processing of Weighed Materials}

The weighed materials were thoroughly mixed and kneaded to remove air bubbles and unwanted materials from the composition as captured in Figure 6. It was then rolled into slabs with the aid of sack board and rolling pin as highlighted in Figure 7. Afterwards, the slabs were cut into rectangular shapes to suit the shape of containers.

In order to prevent the constructed slabs in Figure 8 from warping during leather hard stage, the slabs were packed on flat boards with little load on top as displayed in Figure 9 and turned intermittently to ensure slow and uniform drying at that state. 


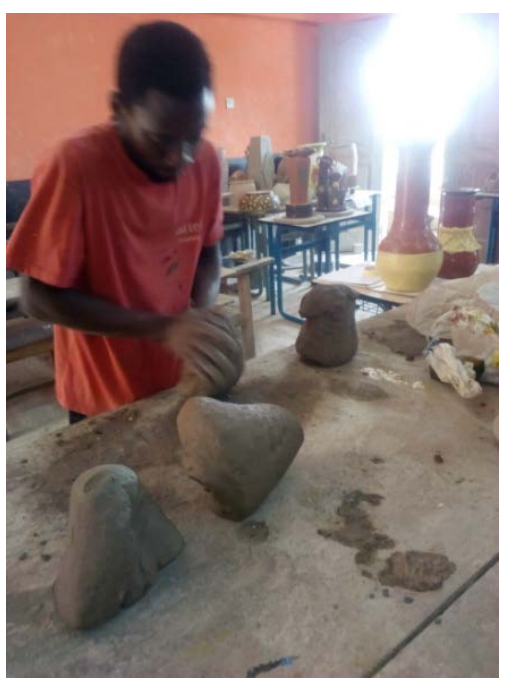

Figure 6. Kneading of clay.

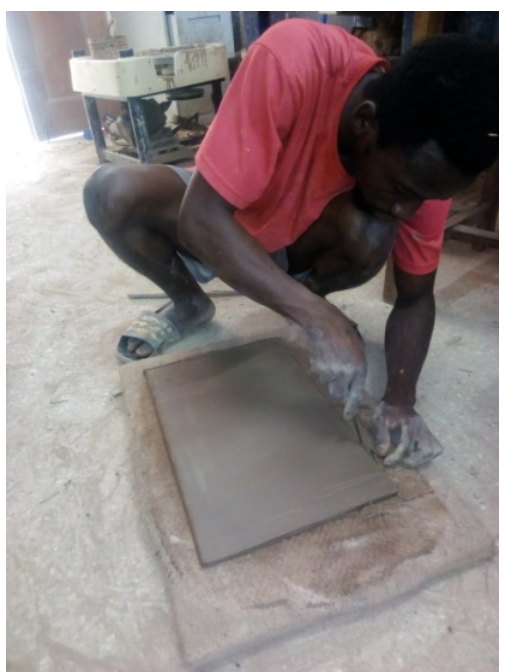

Figure 7. Cutting of slab into shape.

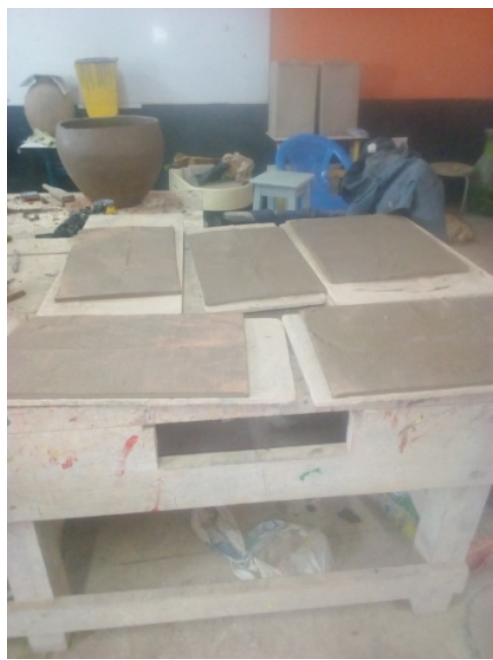

Figure 8. Drying of constructed slabs. 


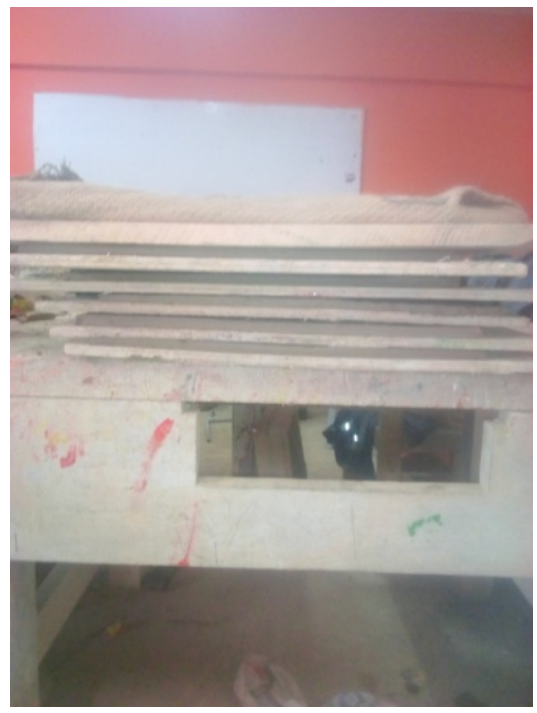

Figure 9. Packed slabs with load on top.

\subsubsection{Construction of Clay Containers}

After the leather hard stage, the slabs were measured to the required height of 55 $\mathrm{cm}$ and base of $30 \mathrm{~cm}(55 \mathrm{~cm} \times 30 \mathrm{~cm})$, scored and joined together with the help of clay slip to form clay containers with lids (Figures 10-12). The joining was well executed especially at the joints otherwise; there could be break off after drying or firing of the containers.

The same procedures were repeated to produce all the five clay containers $\left(\mathrm{C}_{1}\right.$ to $\mathrm{C}_{5}$ ). After construction, the clay containers were allowed to dry gradually. The essence of slow drying was to avoid cracking and warping of the wares as rapid drying could result in these deformities.

Composition $C_{5}$ was purposefully perforated as shown in Figure 13 to allow fresh air to enter the container. It was to find out if allowing air to penetrate the container could play major role in assisting foodstuff to get rotten quickly in the experiment (Figure 14).

\section{Results and Discussions}

\section{Observation Made after Firing of Containers}

The dried containers were successfully fired in a gas kiln. The maturing temperature of the containers was $980^{\circ} \mathrm{C}$ determined by the pyrometer of the kiln. It was observed that even though the containers were initially of the same heights, after firing the rate of shrinkage differed from one container to another. This was attributed to varied body compositions of the containers (Figure 15).

The set up was carried out to experiment on the abilities of the containers to store plantains and extend its lifespan. The bunch of plantain was purchased from a plantain seller in the Takoradi Market Circle where the plantain sellers also find it difficult to preserve their foodstuffs. The plantains were carefully packed and sealed in the containers $\left(C_{1}\right.$ to $\left.C_{5}\right)$ as shown in Figure 16 and Figure 17 respectively. 

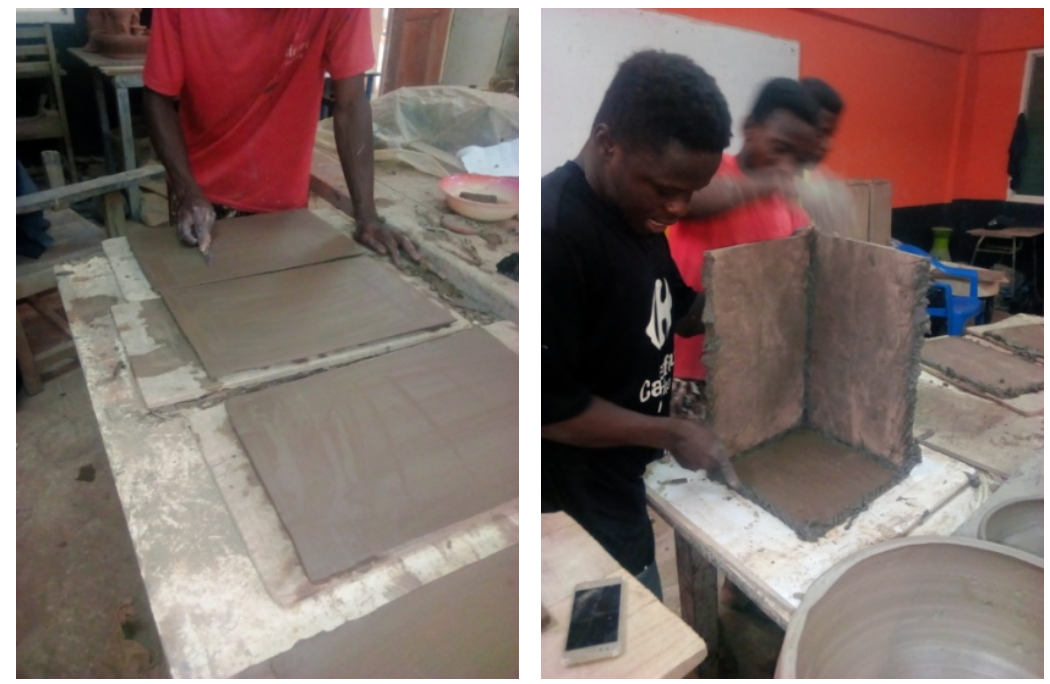

Figure 10. Applying slip and joining of parts of container.
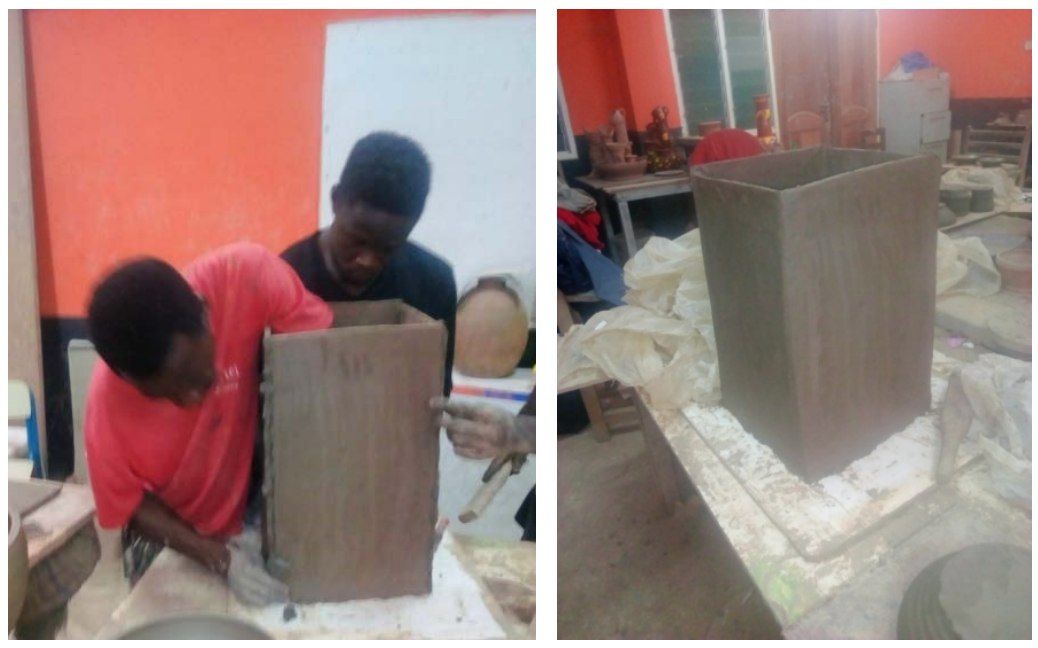

Figure 11. Assembling parts of container.
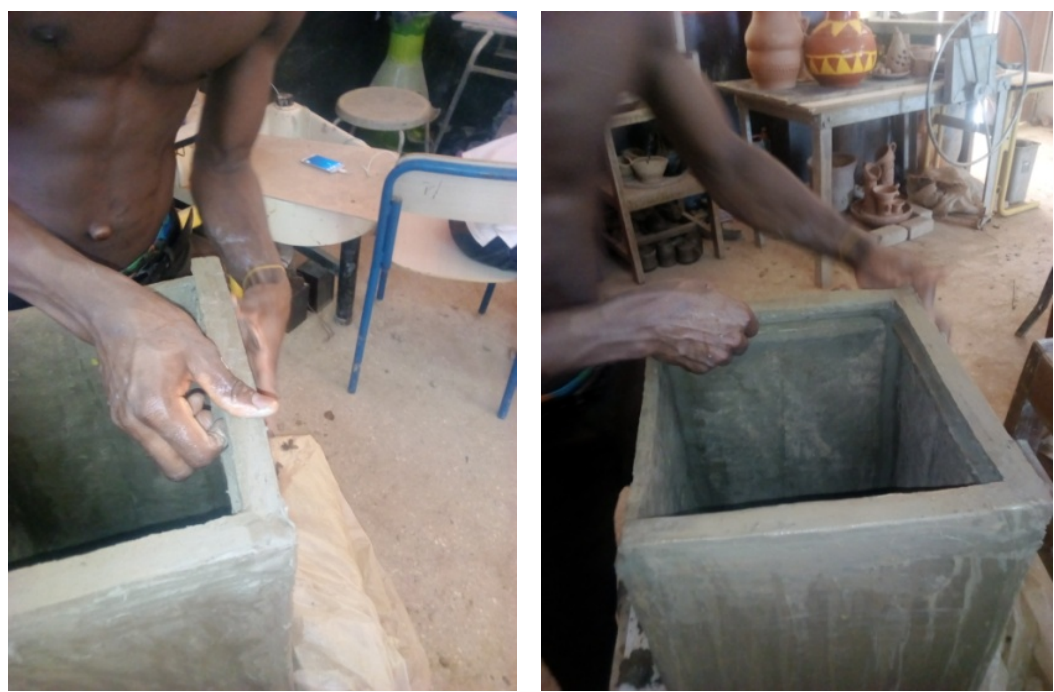

Figure 12. Constructing lids of container. 

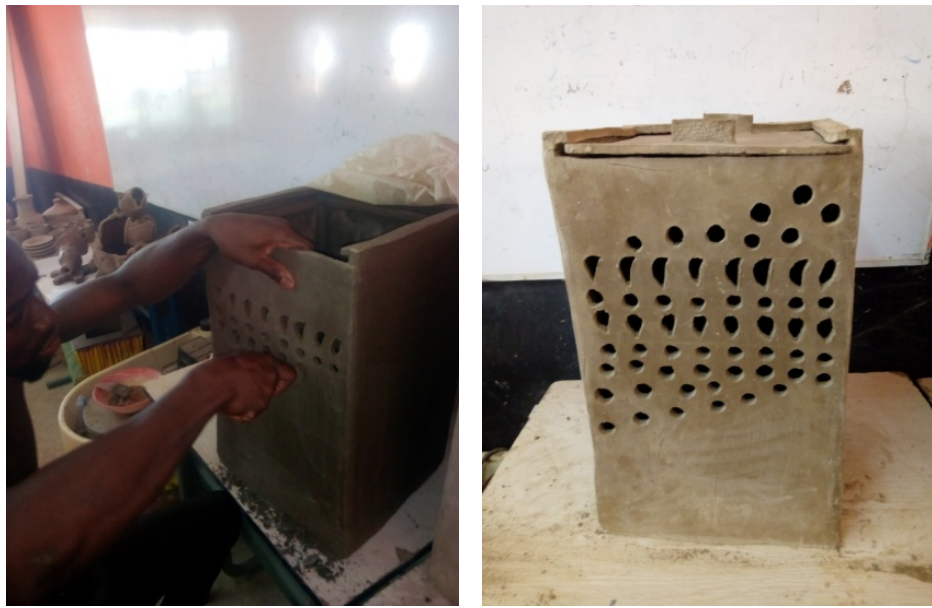

Figure 13. Perforated holes on container $\mathrm{C}_{5}$ for air penetration.

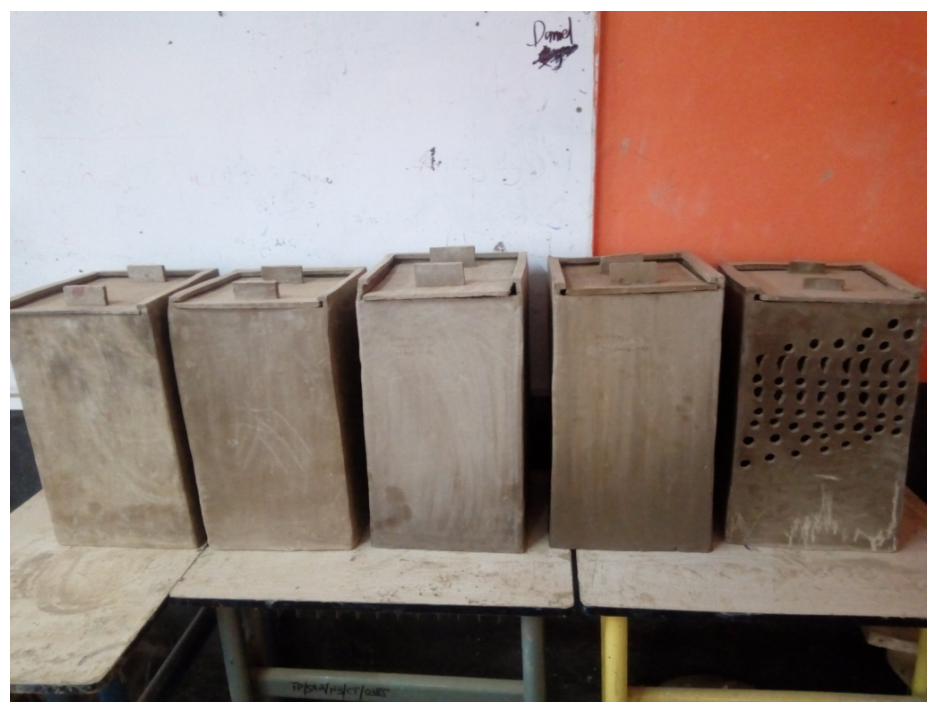

Figure 14. Gradual drying of clay containers $\left(C_{1}\right.$ to $\left.C_{5}\right)$.

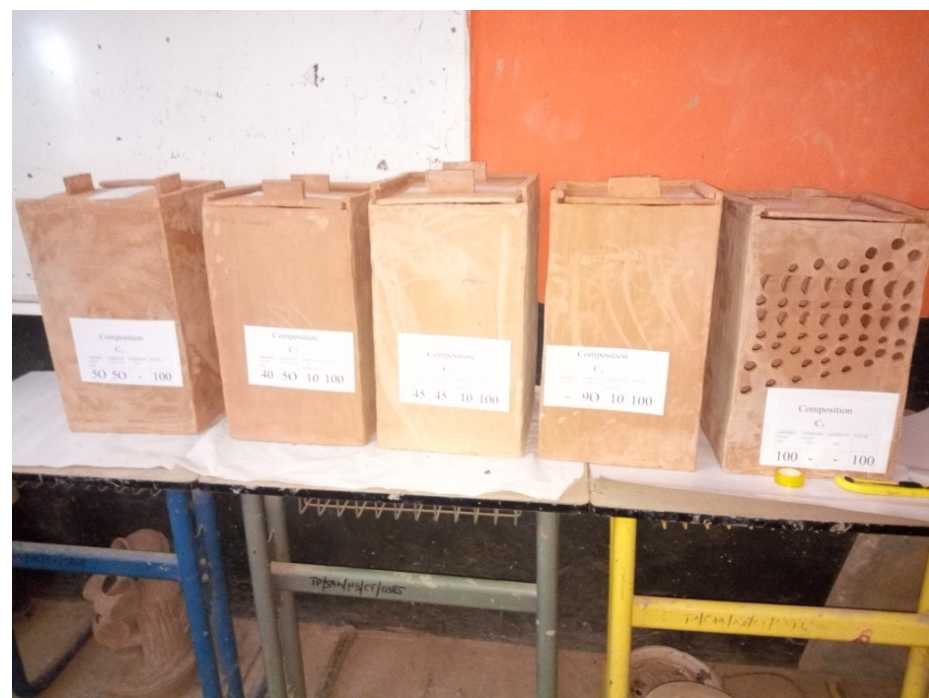

Figure 15. Fired clay containers $\left(C_{1}\right.$ to $\left.C_{5}\right)$. 


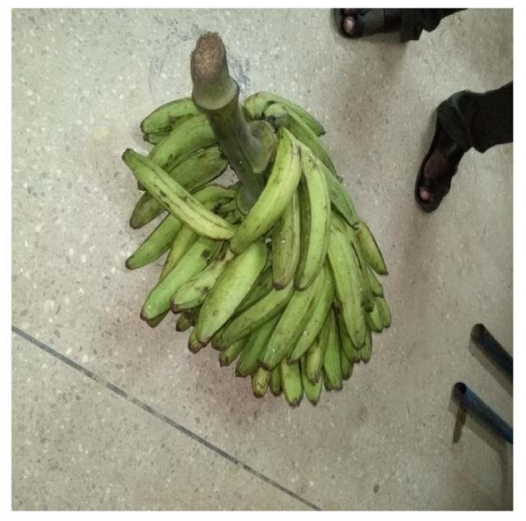

(a)

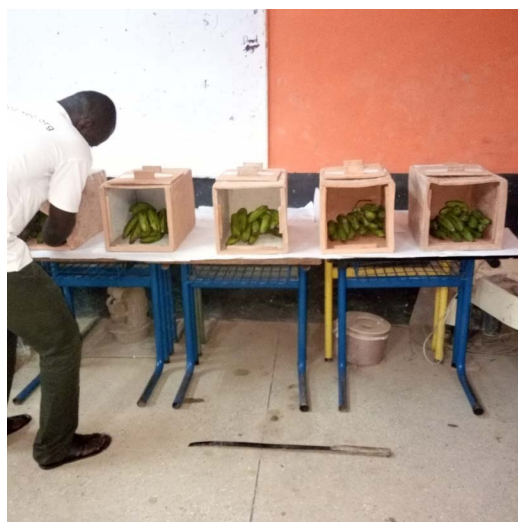

(b)

Figure 16. (a) Fresh plantains; (b) Packing of plantains into containers.

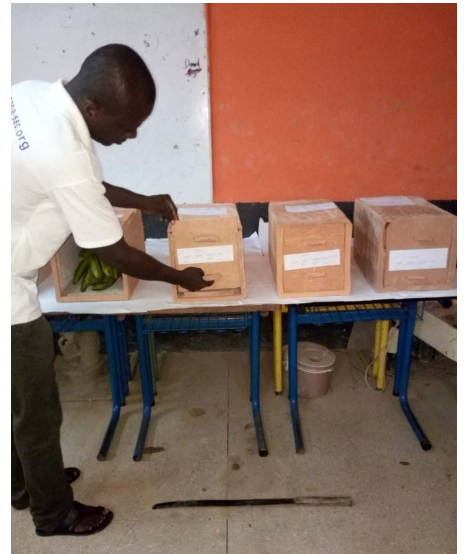

(a)

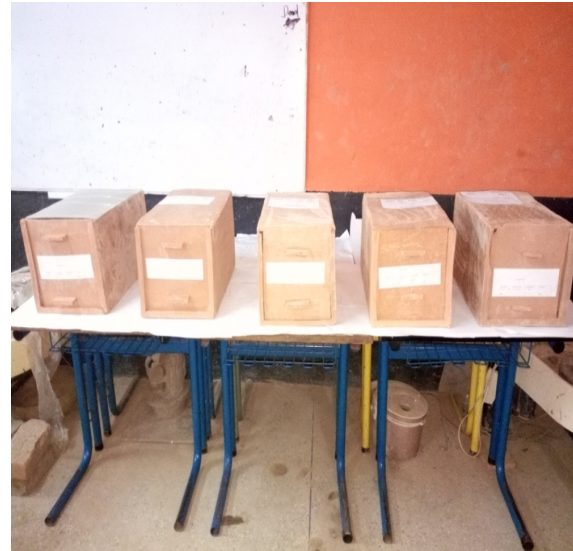

(b)

Figure 17. (a) Closing of clay containers; (b) Sealed clay containers of fresh plantains.

A control experiment (uncovered plantains) was also set up in an open space to ripe in order to compare it with the ones in the containers. It was realized that the uncovered plantains took seven (7) days to ripe as its states have been shown in Figure 18(a) and Figure 18(b) respectively. This confirms Asarewaa's [5] assertion that, fresh plantains take less than two weeks to get rotten at the Ghanaian market centres.

From Table 4, the analysis of weekly recordings of storage/state of plantain in containers was carried out. It was revealed that the plantains were fresh in all the containers for day one. The state of plantains in week two (2) for container $C_{1}$ was partially fresh, $\mathrm{C}_{2}$ was also partially fresh, $\mathrm{C}_{3}$ was fresh, $\mathrm{C}_{4}$ was also fresh and $\mathrm{C}_{5}$ was ripped. Recordings for week three (3) indicated $C_{1}$ as ripped, $C_{2}$ was also ripped, $\mathrm{C}_{3}$ as partially ripped, $\mathrm{C}_{4}$ as still fresh and $\mathrm{C}_{5}$ as very ripped. In week four (4), the recordings of state of plantains were very ripped in both $\mathrm{C}_{1}$ and $\mathrm{C}_{2}$, ripped in $\mathrm{C}_{3}$, partially fresh in $\mathrm{C}_{4}$ and over ripped in $\mathrm{C}_{5}$. The last recordings of state of plantains in containers were in week five (5). It came to light that $\mathrm{C}_{1}, \mathrm{C}_{2}$ and $\mathrm{C}_{5}$ were over ripped; $\mathrm{C}_{3}$ was much ripped while $\mathrm{C}_{4}$ was ripped at the end of the recordings of states of plantains. It was realized that plantains in $\mathrm{C}_{5}$ started 
ripping in week two (2) and could be attributed to perforation of holes in the container. It implied that circulation of air in the container affected the plantains to ripe early. The state of plantains in the various manufactured clay containers after the five (5) week recordings had been shown in Figure 19.

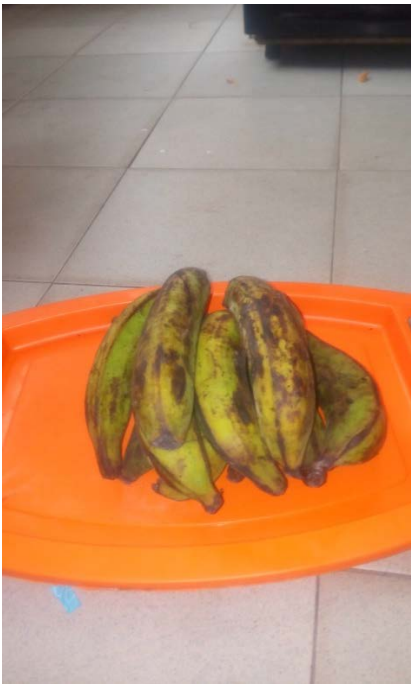

(a)

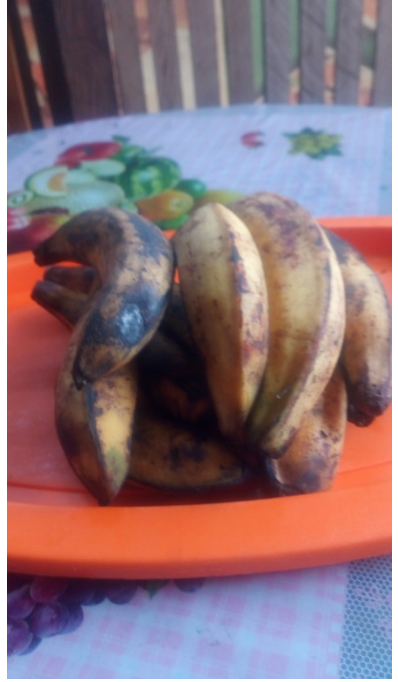

(b)

Figures 18. (a) and (b) States of control experiment (uncovered plantains) for day 4 and day 7. (a) Day 4; (b) Day 7.

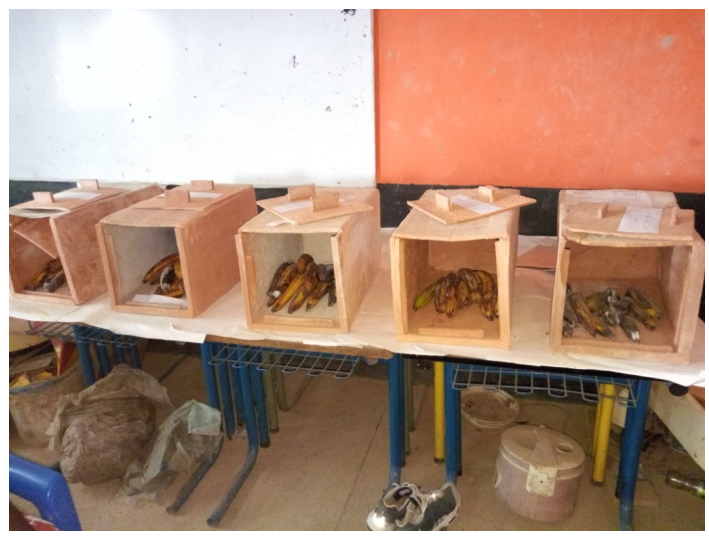

Figure 19. State of plantains in the containers after the period of recordings.

Table 4. Weekly recordings of storage/state of plantain in containers.

\begin{tabular}{cccccc}
\hline Composition & $\begin{array}{c}\text { Storage/state } \\
\text { of plantain } \\
\text { per week 1 }\end{array}$ & $\begin{array}{c}\text { Storage/state } \\
\text { of plantain } \\
\text { per week 2 }\end{array}$ & $\begin{array}{c}\text { Storage/state } \\
\text { of plantain } \\
\text { per week 3 }\end{array}$ & $\begin{array}{c}\text { Storage/state } \\
\text { of plantain } \\
\text { per week } 4\end{array}$ & $\begin{array}{c}\text { Storage/state } \\
\text { of plantain } \\
\text { per week 5 }\end{array}$ \\
\hline $\mathrm{C}_{1}$ & $\mathrm{~F}$ & $\mathrm{PF}$ & $\mathrm{R}$ & $\mathrm{VR}$ & OR \\
$\mathrm{C}_{2}$ & $\mathrm{~F}$ & $\mathrm{PF}$ & $\mathrm{R}$ & $\mathrm{VR}$ & OR \\
$\mathrm{C}_{3}$ & $\mathrm{~F}$ & $\mathrm{~F}$ & $\mathrm{PR}$ & $\mathrm{R}$ & $\mathrm{VR}$ \\
$\mathrm{C}_{4}$ & $\mathrm{~F}$ & $\mathrm{~F}$ & $\mathrm{~F}$ & $\mathrm{PF}$ & $\mathrm{R}$ \\
$\mathrm{C}_{5}$ & $\mathrm{~F}$ & $\mathrm{R}$ & $\mathrm{VR}$ & $\mathrm{OR}$ & OR \\
\hline
\end{tabular}

Note: $\mathrm{F}=$ Fresh, $\mathrm{PF}=$ Partially Fresh, $\mathrm{R}=$ Ripped, $\mathrm{VR}=$ Very Ripped, $\mathrm{OR}=$ Over Ripped. 


\section{Conclusions}

It has emerged from the study that it took only seven (7) days for the control experiment (uncovered plantains) to get ripped while in all the five containers $\left(C_{1}\right.$ to $C_{5}$ ), it was container $C_{3}$ composed of $45 \%$ Abonko clay, $45 \%$ Daboase clay and $10 \%$ smooth sawdust that had very ripped plantains; and $\mathrm{C}_{4}$ made up of $90 \%$ Daboase clay and $10 \%$ rough sawdust had ripped plantain at the end of five (5) week recordings of states of plantains in the manufactured clay containers. It can therefore be concluded that container $\mathrm{C}_{4}$ became successful by extending the shelf-life of fresh plantains to ripe state in five conservative weeks instead of normal period of less than two weeks for fresh plantains to ripe.

Based on the above conclusion, the following recommendations are made:

1) The technique should be made available to stakeholders such as Ministry of Food and Agriculture (MOFA), plantain farmers and market plantain sellers through seminars, public education and symposia in order to minimize post harvest losses.

2) Other perishable crops such as banana should be experimented to find out if the composed clay container can expand their potential shelf-life.

3) The researchers should improve on the study by enlarging the size of the manufactured container to accommodate plenty of plantains in order to ascertain its dependability.

4) Further studies should be scientifically conducted to find out the chemical properties of Daboase clay and be related to other clays to facilitate their usage in the manufacturing of clay containers. Additionally, preserved plantains in clay containers should be investigated if they have any health hazards on human consumption.

\section{Conflicts of Interest}

The authors declare no conflicts of interest regarding the publication of this paper.

\section{References}

[1] Adongo, V. (2018) Executive Director, Peasant Farmers Association of Ghana (PFAG) Post Harvest Losses in Ghana. Interview Conducted on Thursday, 05/12/18.

[2] Ghana Statistical Service (2008) Report of the Fifth Round of Ghana Living Standard Survey. http://www.statsghana.gov.gh

[3] Asmaru, G., Samuel, S. and Subramanian, C. (2013) Assessment of Fruit Management in Gondar Town Markets of North Western Ethiopia. Global Journal of Biology, Agriculture and Health Science, 2, 4-8.

[4] Asiedu, M. (2018) Lecturer, Department of Hospitality Management, Takoradi Technical University.

[5] Asarewaa, Y. (2018) The Life-Span of Plantain at Market Centres. Plantain Seller, Market Circle, Takoradi. Interview Conducted on Tuesday, 11/09/18.

[6] Hagan, J. (2018) Lecturer, Department of Hospitality Management, Takoradi Technical University. 
[7] Rahman, M.S. (2014) Handbook of Food Preservation. 2nd Edition, CRC Press, Taylor \& Francis Group, New York.

[8] Rigg, J., Bebbington, A., Gough, V.K., Bryceson, D.F., Agergaard, J., Fold, N. and Tacoli, C. (2009) The World Development Report 2009. "Reshape Economic Geography": Geographical Reflections. Transactions of the Institute of British Geographers, 3, 128-136.

[9] Brummell, D.A. (2006) Cell Wall Disassembly in Ripening Fruit. Functional Plant Biology, 33, 103.

[10] Krishnan, V. (2014) Study of Traditional Methods of Food Preservation, Its Scientific Understanding and Technological Intervention. Final Report, ISTP (Group-7).

[11] Mack, L. (2001) Food Preservation in the Roman Empire. University of North Carolina, Chapel Hill.

http://www.unc.edu/courses/rometech/public/content/survival/LindsayMack/Food Preservation.htm

[12] Kitinoja, L. and Kader, A.A. (2002) Small-Scale Postharvest Handling Practices: A Manual for Horticultural Crops. 4th Edition, University of California, Davis.

[13] Koduah, K.A. (2018) Identification of Major Causes of Post-Harvest Losses among Selected Food Crops in Market Circle, Takoradi for Proffering Veritable Solutions. Unpublished B. Tech Thesis, Department of Hospitality Management, Takoradi Technical University, Sekondi-Takoradi.

[14] Gebru, H.B. (2015) Extent, Causes and Reduction Strategies of Postharvest Losses of Fresh Fruits and Vegetables-A Review. Journal of Biology, Agriculture and Healthcare, 5, 49-64.

[15] Kesse, G.O. (1985) The Mineral and Rock Resources in Ghana. A. A. Balkema, Rotterdam, 612 . 